\title{
Mexico: a regional power or a failed State?
}

Karol Derwich'

\section{Abstract}

Mexico has been perceived as one of the most important countries in Latin America and the Caribbean region for many years. This opinion has strong foundations. Territory, geographical location, economy, and political influence are the key factors that predestine this country to the role of a regional power. The democratic transition that has taken place in Mexico in last decades and economic cooperation with the United States also allow it to play a role of regional leader. However, Mexico has significant problems that make it difficult for the country to play the role of a real leader. The most important one is the development of narcobusiness. This phenomenon brings not only the growing activity of drug cartels but also the eruption of narcoviolence in Mexico. This gives rise to grave problems for the Mexican authorities. The development of narcobusiness is partially the result of weakness of some of its institutions. For example, police forces do not carry out their tasks and are closely related to the drug cartels. As a result, the Mexican state is incapable of assuring security to its citizens - one of the most important functions of every state. Is it able to control its territory? It definitely does not have a monopoly for the use of violence on its territory. Huge corruption enables different non-state actors to influence decision making processes. All these problems make substantiated theses that the Mexican state is dysfunctional in some areas. Some analysts go much further in their opinions and describe Mexico as a failed state.

The aim of the paper is to analyze the present position of Mexico in Latin America and the Caribbean region. Are the contemporary problems so big that they can lead to the collapse of the Mexican state or does Mexico have a real potential to play the role of a local leader and regional power? The author would like to analyze the impact of the present day internal problems in Mexico's geopolitical position.

Keywords: Mexico. Failed states. Foreign policy

I Ph.D, professor do Instituto de Estudos Americanos e Emigração Polonesa, Uniwersytet Jagielloński, Cracóvia Polônia.E-mail:karol.derwich@uj.edu.pl 


\section{Introduction}

Since the beginning of the $21^{\text {st }}$ century, global international relations have become the scene of several important phenomena that are changing the nature of contemporary world. We are eyewitnesses of the globalization process that is changing the world into a global village. Thanks to new technologies, we can travel through the world without leaving our home. Globalization has also had a huge impact on international relations. An opposite trend toward a deeper regionalization and regional cooperation can be observed on the other side (DERWICH, 2009, p. 15). This process is the result of special international correlations connected with the geopolitical position, economic development as well as the cooperation of countries within the frames of a territory, related to a community of interests (MALENDOWSKI, MOJSIEWICZ (eds.), 1998, p. 218). Irrespective to the definition of regionalism, it is beyond doubt that in the contemporary world, states are not able to develop alone, neither economically nor politically. Hence, the effect of regionalism is a progressive regionalization understood as a separation of regions on the basis of different criteria and regional policies of the countries in a specific region. Also, it seems that the contemporary international system is going toward a multilateral model. After the cold war period that was characterized by bipolar competition, there was a period of the unipolar dominance of the United States which, at the turn of the $20^{\text {th }}$ and $21^{\text {st }}$ century, could have claimed itself a unique superpower. Meanwhile, the contemporary international system is changing toward greater multipolarity. It's not only the United States that determine international relations and have the ability to influence different regions of the world. China is known from its global aspirations for many years. The European Union is an important global power. Japan, despite its economic problems, still is one of the largest world economies, which permits it to play the role of global economic power. The conflict in Ukraine demonstrates that years after the collapse of the Soviet Union, Russia is returning to its imperialistic traditions, mostly from the post-Soviet area. Also, new actors of the international system have appeared and are claiming their bigger role on it. Such countries as members of the BRIC group: Brazil, India China and Russia can be mentioned. 


\section{Mexico's foreign policy at the turn of the $20^{\text {th }}$ and $21^{\text {st }}$ century}

Taking this changing nature of the contemporary international system into consideration, what is the place and role of Mexico? Mexico has, for many years, been perceived as one of the most important countries in Latin America and the Caribbean region. This opinion has strong foundations. Territory, geographical location, economy, and political influence are the key factors that have predestined this country to the role of a regional power. The democratic transition that has taken place in Mexico in the last decades and economic cooperation with the United States also permit Mexico to play the role of a regional leader. It is necessary to mention the huge importance of structural reforms that were undertaken in Mexico since the 1980s. They also resulted in the growing role of Mexico in the Latin American and Caribbean region. The economic transformation that introduced Mexico to the world of liberal economies increased its role as an important actor in Latin America. The democratic transition was also not without meaning. Those process changed hitherto situation of Mexican state both in the internal and external dimensions. The statement that in the first years of the $21^{\text {st }}$ century Mexico became a country of open economy, unequal society and unconsolidated democracy seems accurate. All these elements have had an impact on Mexican foreign policy (GONZALEZ GONZALEZ, 2001, p. 621).

In analyzing Mexican foreign policy in the last years one can reach the conclusion that since the beginning of the $21^{\text {st }}$ century it is more and more influenced by internal factors. The economic opening resulted in Mexico's strong interest in broadening its economic relations not only with Latin American countries. The principle was building a strong relationship with the northern neighbor and the world's largest economy - the United States. It can be concluded that the outcome of those efforts was the successful conclusion of negotiations over the free trade agreement that entered into force on January $1^{\text {st }}, 1994$ in the form of North American Free Trade Agreement between Mexico, the United States and Canada. However, the economic transition that led to the total transformation of the Mexican economic and developmental strategy also led to looking for other possibilities of broadening its commercial opportunities. In 1997, Mexico ratified an agreement with the European Union that entered into force in 2000 (EUROPEAN COMISSION, 2014). 
On May 17, 2008 Mexico and the European Union agreed on a "strategic association" to further advance trade liberalization and to address climate change issues (VILLAREAL, 2012). In the last two decades Mexico signed plenty of free trade agreements with countries from all over the world. That demonstrates how strongly the economic transformation impacted and still impacts its foreign policy. At present, Mexico is one of the largest supporters of free trade in Western Hemisphere. This was particularly visible during the negotiations over the idea of Free Trade Agreement of the Americas (FTAA/ ALCA). However, during the first years of negotiations, Mexican diplomacy was quite cautious as it did not want to share the benefits of free trade with the US with other Latin American countries. At the beginning of the $21^{\text {st }}$ century, Mexican President Vicente Fox supported the idea even more strongly than George W. Bush's administration. During the $4^{\text {th }}$ Summit of the Americas in Mar del Plata, it was Fox who most strongly campaigned for the continuation of negotiations since George W. Bush was already concentrating on security and the war on terror (GUJARDO SOTO, 2008, p. 293).

As it was already mentioned, the process of democratization in Mexico also had its important impact on Mexican foreign policy. Firstly, the process of decision making - also in the area of foreign policy - changed as a result of breaking PRI domination. Although, the President maintained his dominant position in foreign policy making, the new distribution of power - basically in Congress but also in the presidential administration - weakened its position in political system in general (RUIZ PEREZ, 2011, p. 314). This was particularly visible during the Zedillo presidency and during the presidential terms of Fox and Calderón. Democratization brought along several effects in the area of foreign policy. The political transformation meant more representation in all branches of power, principally in the legislative one. This meant that differences of opinions among the society on the issue of foreign policy were manifested publicly. This was enforced by the democratizations of the mass media that produced a better flow of information from the government level to the citizens. Also, as a result of political openness, problems of foreign relations became the subject of internal political competitiveness (RUíZ PÉREZ, 2011, p. 328). Nevertheless, it would be an untruth to conclude that the democratization process affected the area of foreign policy in a negative manner. The decision making process is more complicated in the conditions 
of divided authority but it was still the President who was the main actor in the area of foreign policy. This is another example of internal factor's impact on external affairs.

As economic liberalization and democratic transition can be perceived as positive elements of internal changes and their positive influence on foreign policy, negative phenomena that affected Mexican foreign relations could also be observed for the past several years in the country. A few years ago opinions about Mexico as being a failed state appeared. This is the consequence of increasing the power of organized crime - principally drug cartels - and a huge wave of violence that erupted several years ago. The so called 'war on drugs' declared by Felipe Calderón soon after his assumption of the presidency in 2006 neither restricted the activity of drug cartels nor helped to improve security in Mexico. The lack of public security and the continuous development of narcobusiness is a growing internal problem that also constitutes significant challenges in the area of foreign relations. As the opinions that claim Mexico a failed state are too far-reaching, there is no doubt that Mexico suffered a deep dysfunction in the area of public security.

\section{Failed state or dysfunctional state?}

It is important to see the difference between the dysfunction of a state and the term failed state. In recent years it became quite common to use the latter term in reference to the countries that had significant problems with the functioning of their institutions and with the fulfillment of their obligations toward their own citizens. However, using this term is not always suitable for the description of a state. The term was popularized by the Fund for Peace US think tank and Foreign Policy magazine which publish the Fragile States Index $x^{2}$ on an annual basis. In fact, only countries from the top of the ranking can be described as truly failed states. There are still some doubts in this situation. Is it justified to use the term failed state in the case of a country that never had a solid state institutions? If something failed, it would have had to have previously been successful. This constitutes a significant question about the very nature of the term 'failed state'. There is also a question as to when a state can be described as a failed one? The Fragile State Index - the

2 Until 2015 the ranking was titled the "Failed States Index". 
most prestigious study related to the condition of the states - is based on a broad set of factors. However, it doesn't give a precise answer when the state is a failed one, is it a place in the top ten or top twenty or top fifty etc. That is why it seems more appropriate to speak about the dysfunction of states. When using this term, it is possible to point out the nature of a state's problems with large precision, without the necessity of describing it as a failed one. The distinction between the term failed state and dysfunctional state is one of the conclusions of the research project carried out at the Institute of Political Science and International Relations of the Jagiellonian University (KŁOSOWICZ (ed.), 2013, pp. 11-36). Mexico was one of the case studies analyzed during that project. This was justified as, several years ago, some of the annalists used the term failed state to describe Mexico's situation related to the growing development of drug cartels and the state's inability to stop the huge waves of violence. It is beyond any doubt that the most serious problem of contemporary Mexico is the lack of public security, violence and human rights violations. The numbers confirm this situation. During the Felipe Calderón's presidential term, the war on drugs resulted in over 60 thousands deaths. In 2012, more than 26 thousand persons were killed. The homicide rate is 22 per 100 thousand citizens (INEGI). This is the basic reason for Mexico being perceived as a failed or failing state. However, is the huge number of fatalities and the unprecedented wave of violence enough to call Mexico a failed state?

\section{Dysfunction of the Mexican state}

The very nature of Mexican state after the Mexican revolution in the first decades of the $20^{\text {th }}$ century must firstly be emphasized. The aim of the new political force that emerged from the revolution and finally formed in the Institutional Revolutionary Party (Partido Revolucionario Institucional PRI) was to create strong institutions that would replace the caudillos - strong regional politicians that destabilized Mexico through the $19^{\text {th }}$ century and established dictatorial rules. This specific political system created in Mexico was based on a broad bureaucratic apparatus and strong institutions, both dominated by the PRI. Despite ousting the PRI from power at the turn of the $20^{\text {th }}$ and $21^{\text {st }}$ century, the political system generally remained the same. A general weakening of the position of the president could be observed, however 
this is not the effect of structural reforms but the inability of the presidential parties to win the majority in Congress and to serve as an instrument of a president. However, democratization brought changes in less formal spheres to Mexico. As the political system generally remained unchanged, removing the PRI from power resulted in breaking previous connections between the ruling party and different groups of interest. Meanwhile, the drug cartels had already been functioning as one of such groups. During the PRI domination, Mexican authorities tolerated the existence and activity of drug cartels if those restricted violent actions. The appearance of the new authorities after Vicente Fox's presidential victory created a new situation. Relations between the authorities and organized crime - based on clientelistic connections were broken. This constituted the situation of conflict. Simultaneously, at the beginning of the $21^{\text {st }}$ century several drug cartels gained such immense power and possibilities that it created a new situation in relations between the state and organized crime. It was no longer the state and its authorities that could dictate the conditions of those relations. The growing power of the Mexican drug cartels was the effect of the continuous and intensive demand for illicit substances in the United States. This made drug trafficking an extremely profitable business. It ensures a huge income for organized crime. Those funds are used for creating new routes of trafficking illicit substances to the United States, for buying the newest and most advanced weapons in the United States and for corrupting important officials of the Mexican state. Since the beginning of the $21^{\text {st }}$ century it was no longer the state and its authorities that could determine the nature of the relations with the drug cartels. Since then, the cartels have had the possibilities and instruments to dictate the conditions of those relations. The governments, especially the administration of Felipe Calderón responded to this new situation through the militarization of its anti-drug policy and through the declaration of the so-called war on drugs.

This extraordinary empowerment of narcobusiness in Mexico led to a deep dysfunction of the state in certain spheres. However, this was possible due to the state's inability to respond to the growing danger from organized crime. The situation of the Mexican police force is a good example of such a situation. The institutions which are dedicated to ensure internal security and legal order have not been able to carry out their basic functions and obligations for the past several years. Several reforms of the Mexican police 
forces have taken place in recent decades. It was Presidents Zedillo, Fox and Calderón who had undertaken the challenge of reforming the police and making this force more effective in combating organized crime and in ensuring security to the citizens. Corruption is the main problem of Mexican police forces. This is one of the most corrupted institutions in Mexico. In research conducted by the Transparency International in 2013, 90 percent of respondents answered that the police is a corrupted or extremely corrupted institution (TRANSPARENCY INTERNATIONAL, 2013). This leads to serious pathologies. A significant percentage of policemen cooperate closely with drug cartels. Some of the analysts say that in Mexico can be observed a process of privatization of the police because a lot of its members also work for criminal groups (AGUILAR, CASTAÑEDA, 2009, pp. 33-34). What is particularly important, corruption does not only touch lower level police officers. There were several huge scandals due to the cooperation of the most important persons in the Mexican police and agencies responsible for combating narcobusiness with drug cartels. One of the most important examples of the corruption and collaboration of the top officers was the detention of Jesús Gutiérrez Rebollo, the head of the National Institute for Drug Combating (Instituto Nacional de Combate a las Drogas), who was accused of collaborating with the Juarez cartel. This profound dysfunction of the police forces that led to the inability to fulfill its basic tasks and to successfully combat the organized crime is presently perceived as one of the principal problems of the Mexican authorities. This also significantly preoccupies Mexican neighbors, mainly the United States. The George W. Bush administration, disturbed by the growing violence and increasing activity of Mexican drug cartels, decided on extended cooperation with the Mexican authorities. In March 2007, President Felipe Calderón and President George W. Bush announced, in Merida, a significant strengthening of cooperation between the two countries and substantial US assistance for the Mexican government in its struggle against narcobusiness. This is commonly known as the Merida Initiative. In the framework of this cooperation, the United States is currently providing technical expertise and assistance to Mexico for police professionalization, prosecutorial capacity building, judicial and prison reform, justice sector institution building, information technology enhancement, infrastructure development, and border security. More than one-third of a billion dollars worth of equipment 
and assistance was delivered to Mexican government agencies through the end of 2010, with approximately another USD 500 million scheduled for delivery in 2011 (PUBLIC PAPERS OF..., 2007, PP. 314-316).

The profound dysfunction of the Mexican state in the area of public security is also created by the huge inefficiency of the judicial system. Statistics are disastrous for the Mexican authorities. According to them, less then 10 percent of trials end with a sentence. Due to the extremely low efficiency of the judicial system, an alarmingly low number of delinquencies is reported to the police (RIBANDO SEELKE, 2013). Also, the judicial system is perceived by the citizens as being strongly corrupted. In 2007, almost 60 percent of respondents declared a lack of confidence in the judicial system (SHIRK, 2010, p. 192). This grave inefficiency of the system results in a broad confidence that there is no danger of being captured and sentenced. And even if criminals are arrested, organized crime has a lot of possibilities to evade punishment. The problem that results from this inability of the judicial system to realize its functions is not easy to resolve for the government. Although the permanent lack of funds needed for building a more efficient judicial system is a serious problem, there are much more complicated dilemmas. First of all, the judicial system is the less reformed one. It still functions on the basis created during the authoritarian system. That opens doors for a lot of negative tendencies. It is particularly visible in the organization of the office of the attorney general. The lack of transparent rules related to the activity of the office results in permanent accusations about corruption. In the present conditions the previous construction of the office of the attorney general in Mexico is unclear and does not help to resolve the problem of organized crime.

The effect of the extended dysfunction of Mexican state in the sphere of security is the growing role of the military in ensuring internal order. This is always very risky as the military is not the institution dedicated to internal affairs - its objective is to secure independence, sovereignty and territorial integrality, not to fight with organized crime and ensure a legal system. This is why, the use of military force usually brings increase of human rights violations. In effect, the increasing level of insecurity and the growing dysfunction of Mexican state institution can bring very dangerous results in the future. The permanent inability of the State institution to carry out its 
principle function can lead to an increase of antidemocratic attitudes among the citizens of those countries. Although in Mexico the support for democracy is quite high or does not differ strongly from the other countries in the region, in other cases - as for example in Guatemala - this seems to be a significant problem. The government is losing its control over the political process and is unable to match people's expectations and demands. One of the results of this weakness and inefficiency is the number of people living in poverty (OPHI, 2011). State's inability to combat organized crime is especially dangerous at present. It is of fundamental meaning as the growing activity of Mexican drug cartels in Guatemala can be observed.

\section{A regional power?}

At this situation a huge importance has a question about the role of Mexico in the region. Is this a state that can be a regional power, or, due to its dysfunction in the sphere of security, is this rather a destabilizing factor? At first glance, this question can be deemed as strange. This is because since the half of the $20^{\text {th }}$ century, Mexico has elaborated a strong position in the Latin American region. It also possesses most of the attributes that a state needs to be a regional power. This is the third largest country in the Latin American region with the total area of $1,964,375 \mathrm{sq} \mathrm{km}$. Its geopolitical location is extremely important. Geographically it belongs mostly to North America (the very south of Mexico belongs to the Central American isthmus). Culturally, however, Mexico is an integral part of the Latin American region. It has an important impact on Mexican foreign policy, as strategies were already in place to play the role of a kind of bridge between Latin American and the United States. Mexico has two coasts: the east one on the Gulf of Mexico, Caribbean Sea and Atlantic Ocean, and the west one on the Pacific Ocean. It opens Mexico both to the West and to the East. This has also played a significant role in the history of Mexico. Already in the colonial times Spaniards wanted Mexico to be a middle point between the Spanish colonies in the Far East, the New World and a metropolis in the Iberian Peninsula. Contemporary Mexican diplomacy is also conscious of the advantages constituted by access to two oceans. Since the economic transformation at the turn of the 1980s and 1990s, Mexico has been interested in broadening its economic relations with the European countries. The "strategic association" with the 
European Union is a good example. It does not result in disrespect of the Pacific region. Since the beginning, Mexico has been a member of APEC, a broad forum of economic cooperation in the Asia and Pacific region. Also, the last years have brought examples of Mexican activity in the Pacific area. In 2012, together with Chile, Colombia and Peru, Mexico formed the Pacific Alliance. Two Central American countries - Panama and Costa Rica are strongly interested in joining that new integration initiative. The Pacific Alliance differs substantially from recent agreements that tend to be regionally focused, such as the Unión de Naciones Suramericanas (Union of South American Nations-UNASUR, 2004), the Alianza Bolivariana para los Pueblos de Nuestra América (Bolivarian Alliance for the Peoples of Our America-ALBA, 2004), and the Comunidad de Estados Latinoamericanos y Caribeños (Community of Latin American and Caribbean States_CELAC, 2010). Unlike the other groupings, the Pacific Alliance's goal is to deepen cooperation among members with the explicit purpose of forging closer relations with the Asia-Pacific region. Whereas UNASUR, ALBA and CELAC view regionalism and integration as tools for combating globalization, the Pacific Alliance perceives them as critical links to global flows (RAMÍREZ, 2013). Finally, the fact that Mexico initiated its integration with foreign markets in 1994 when it constructed the North American Free Trade Agreement with the United States and Canada, was not without meaning. NAFTA was a historical step, because it was the first time that a Latin American country joined forces with an industrialized partner. Moreover, it became a prototype for other new initiatives in Americas throughout the decade. A series of new free trade agreements (FTAs) throughout the region followed the NAFTA model. For several years, Mexico was the only Latin American country that had signed free trade agreement with the United States.

Those examples of economic cooperation of Mexico in the inter-regional scale show that it was able to play a significant role. This was also possible due to its economic potential. Mexico is an important economy in the Latin American region. In 2012 the value of Mexican GDP was USD 1.178 billion and it was the second result in Latin America, after Brazil (USD 2.253 billion) and far much more than Argentina (USD 475 billion) (WORLD BANK, 2014). The value of foreign direct investments shows that Mexico is a significant economy in the region. It ranks third (USD 15.4 billion) after 
Brazil (USD 76.1 billion) and Chile (PLN 30.3 billion) (WORLD BANK, 2014). It seems that economy is a crucial factor that permits Mexico to play a significant role in the Latin American region.

And finally the political aspect. As it was already mentioned, in the second half of the $20^{\text {th }}$ century it was quite visible that the Mexican authorities had aspirations to ensure Mexico's role as a regional power. This was particularly apparent during the cold war period when Mexican diplomacy implemented a foreign policy aimed at making Mexico a bridge between Latin American countries and the "colossus from the North". In effect, the bilateral relations between the two neighbors are described as relacion especial. In the bipolar world, it was very important for the US authorities that Mexico have a stable government that presented a restrained position toward communism. In effect, Mexico maintained an exceptional independence of its foreign policy from US influence. It was particularly clear after the Cuban revolution when the government of Mexico did not agreed with the US policy toward the revolutionary government of Fidel Castro. This unique - for Latin American conditions - independence of Mexican foreign policy during the cold war guaranteed Mexico a strong position in the Latin American region. It was perceived as an important actor in international relations in the Western Hemisphere. For Mexico, the relations with its northern neighbor always constituted the most important aspect of its foreign policy. Since the end of the cold war, the most important element of this relation was mutual commerce and economy. However, the United States perceived Mexico basically through the prism of its national security. It was visible during both world wars, during the cold war period and it is still present, particularly after 09/11 (OJEDA GÓMEZ, 2010, p. 150). The problem of security in the bilateral relations between Mexico and the US is not limited to the lack of control of the border and the risk of it being used by terrorists to enter the United States. The problem of drug trafficking and illegal immigration to the US is equally important. The question is not whether Mexico is able to improve the situation at the border to a significant degree. There is a real danger that Mexico can be a source of destabilization of the region due to its profound dysfunction in the sphere of security and a total lack of capabilities to lead a successful combat against organized crime.

Mexico has strong neighbors in North America. It would be difficult to question the leadership of the United States. However, the role of Mexico 
Mexico - A Regional Power or a Failed State? | Karol Derwich

in North America is growing, especially since the 1994 and the entrance of NAFTA into force. It is basically the effect of growing connections between the Mexican economy and the US and Canadian ones. It is beyond any doubt that economy and commerce are the foundations of Mexico's relations with the United States and Canada. These relations are of a crucial role for Mexico. About 80 per cent of Mexican export goes to NAFTA partners (SECRETARÍA DE RELACIONES EXTERIORES, 2013). However, as it was mentioned above, the internal problems of Mexico that resulted from its deep dysfunction in the area of security are more and more important and have a strong impact on relations, especially with the United States. Relations with Canada are much less intensive as the volume of commercial exchange is less significant. However, there is a mutual will to intensify bilateral relations between both countries.

It is worth emphasizing that this destabilizing influence of Mexico which is the effect of its deep dysfunction in the area of public security is not limited to the US - Mexican border. The situation in Mexico is destabilizing the Central American region more and more. This is especially visible in the case of Guatemala. As most of the Central American republics suffer from a weakness of the state's institutions they are specially compliant for activity of organized crime. The growing activity of Mexican drug cartels in Guatemala, especially the los Zetas, can be observed. In the effect of the increasing presence of Mexican drug cartels in Central American countries, their leaders decided to formed joint forces to combat narcobusiness on their territories (RUÍZ, J.L., 2011). The escalation of narcobusiness toward the southern neighbors of Mexico constitutes a question about its role in the Central American sub region. Meanwhile the Central American isthmus constitutes a strategic region for Mexico. There are a lot of discussions about the Mexican border with the United States, although Mexico's southern border is also very important. For many persons from Central and South America it is the entry way to North America. This is why one of the priorities for Mexico should be cooperation with its southern neighbors - Guatemala and Belize - to enforce their efforts focused on security along the border. As the Mexican ambassador in Poland explained, the main objectives of Mexico in Central America are the promotion of economic development, human rights protection and supporting democratic transformations VILLANUEVA HALLAL, 2014). 
Although most of the Mexican territory geographically belongs to North America, it is the Central American region where Mexico has an opportunity to be a regional power. It is not only the effect of the fact that Central American republics are small in the sense of territory. For decades, they also have been the place of strong social conflicts that usually turned into bloody civil wars. The most profound crisis took place in the 1980s, when the entire sub region was immersed in the deepest crisis in its history. The Sandinista revolution in Nicaragua, the civil war in El Salvador, the dirty war in Guatemala, the engagement of the United States, Cuba, Soviet Union and other Central American republics all together turn the region in a scene of sharp fighting. At that time, Mexico was one of the founders of the Contadora Group that tried to solve the crisis. Today Mexico has even more potential for playing the role of a regional power. However, as long as the problems of organized crime and dysfunction of the state are not solved, Mexico will continue to be a source of destabilization in the Central American region. Any form of destabilization in the Central American countries is both - highly probable and very dangerous. Countries such as: Guatemala, Honduras, Nicaragua and El Salvador are quite weak states. They are extremely vulnerable to any forms of destabilization. For this reason, the role of a regional power in this region should be the task of strengthening stability and stimulating development. Mexico can presently be attractive for Central American republics mainly in the area of economy. However, US competition is very strong. The signing of the CAFTA and the bilateral free trade agreement between the US and Panama can limit Mexican economic possibilities in the region. This is why it is so important to combat organized crime. The weakness of Central American states is a great encouragement for Mexican drug cartels to develop their activity in these countries.

The United States are at the top of the pyramid countries important for Mexico. The Central American republics and Canada are one step below. Other countries of the Latin American region are in third place. This is natural as one takes the cultural and linguistic similarities as well as common history into account (OJEDA GÓMEZ, 2010, p. 147). Of course, the relations with these countries are different as their importance to Mexico is not the same. Naturally the most important ones are Brazil and Argentina because of their economic potential and political importance. All three countries, Mexico, Argentina and Brazil have aspirations to be regional powers. There 
Mexico - A Regional Power or a Failed State? | Karol Derwich

is a question whether there is enough space in Latin American region for three regional powers? It seems natural that Brazil wants to be the most important actor in Latin America. That is why its relations with Mexico should be carefully observed. The past several years have been a difficult time for these relations. Relations began deteriorating from the very beginning of the Dilma Rousef presidency. The Mexican authorities were not present at her inauguration - President Felipe Calderón and his Secretary of Foreign Affairs were not present. It was the beginning of cooling bilateral relations between the two countries. More difficulties appeared during the last years. Differences on climate issues and growing competition in the international financial institutions, specifically the IMF can be mentioned (SORIANO, 2012, p. 136-137). Also, the perception of cooperation with other regions are distinct in Mexico and Brazil. The first one is principally engaged in strengthening its relations with North American countries. It is necessary to point out Mexico's growing interest in the Asia and Pacific regions. The Pacific Alliance seems to play a decisive role in Mexico's relations with the Far East. As four Latin American countries are now participating in this initiative, the next two - Panama and Costa Rica - are strongly interested in a form of cooperation. Brazil, meanwhile, is interested mostly in developing its relations with the European Union and in strengthening the South - South cooperation. The Mexican engagement in the relations with the Asia and Pacific region can be confirmed in economic data. The value of Mexican commerce with this region in 2012 was almost USD 108 billion while with Europe it was USD 65 billion (SECRETARÍA DE LAS RELACIONES EXTERIORES, 2013).

\section{Conclusions}

Due to its economic potential, commercial links with the Unite States and Canada, and its geopolitical situation, Mexico is an important actor in the Latin American and Caribbean region. Also, history is a factor that can explain Mexico's aspirations to be a regional power. Mexico's international position of the region was substantial especially during the cold war. The political stability, although based on an authoritarian political system, was exceptional on the grounds of Latin America. That permitted the relative independence of its foreign policy from the US tendencies to dominate the 
Western Hemisphere. When the cold war ended, Mexico implemented a huge transformation of its economy that permitted establishing closer commercial links with the United States. That is also exceptional in comparison with other Latin American countries. All these factors can be mentioned as factors that can help Mexico build its position in the Latin American and Caribbean region. However, internal factors are equally important nowadays; meanwhile the situation in Mexico is turning into growing embarrassment. The deep dysfunction of the Mexican State in regard to public security strongly affects its relations with other countries and makes them uncertain about the real condition of the Mexican State. Is it a reliable partner? Is it able to solve its internal problems as they affect other countries to a significant degree, specifically direct neighbors? Finally, the question that constitutes the topic of this paper - is it a regional power or a failed state? It can be stated with strong emphasis that Mexico cannot be described as a failed state. Firstly, this term is highly imprecise. However, the fact that the situation in Mexico does not permit for describing it as a failed state is much more important. Mexico has strong state institutions created decades ago to serve as instruments for the predecessors of the PRI. Despite the political change in 2000, the foundations of the political system have not changed significantly. Mexico has a huge problem with public security that results from the deep dysfunction of the institutions responsible for it. This is why it would be better to call Mexico a state with a deep dysfunction in the area of public security. Does this make it impossible for Mexico to act as a regional power? Not necessarily. It is an important actor in international relations, not only in Latin America and the Western Hemisphere. Nevertheless, it is necessary to emphasize that the growing dysfunctions of the Mexican state are affecting its foreign policy more and more. Without resolving the problem of organized crime, principally narcobusiness, and without a significant improvement of the public security, it will be difficult to aspire to the role of regional power. As it can be observed in the Central American region, Mexico can be source of regional destabilization as drug cartels are expanding their activity to the countries south of Mexico. In this situation, Mexico can be perceived as a source of threat. It will deteriorate mutual relations. A very similar situation could appear in relations with the United States. For several years the issue of security has been - together with economic issues - the most important element of mutual relations. If 
Mexico - A Regional Power or a Failed State? | Karol Derwich

Mexico is a permanent source of destabilization in the border zone and is incapable of restraining organized crime, it can have a devastating impact on its relations with the United States. To conclude, it can be said that Mexico is in a very important moment. As the authorities want to build a strong international position, it is necessary to solve the largest internal problem which is the deep dysfunction related to public security. There is a large probability of the mutual dependency of those two elements: the deeper the dysfunction of Mexican state, the more difficult it will be to play an important role in the region.

\section{References}

AGUilar, V. R., CASTAÑEDA, J. G., El Narco: La Guerra fallida, Punto de lectura, Mexico, D.F., 2009.

DERWICH, K., The U.S. and the New Regionalism In the Western Hemisphere, in: Ad Americam, v. $10,2009$.

EUROPEAN COMISSION. Source: <http://ec.europa.eu/trade/policy/countries-and-regions/ countries/mexico/>. Access: 18.05.2014.

GONZÁLEZ GONZÁLEZ, G., Las estrategias de politica exterior de Mexico en la era de globalización, in: Foro Internacional, Vol. 41, No. 4 (166), Oct. - Dec., 2001.

GUJARDO SOTO, G., Viejos puentes y nuevos acervos. La relación de Mexico con America Latina y el Caribe durante el sexenio de Vicente Fox, in: Foro Internacional, v. 48, n. 1/2 (191/192), Jan. - Jun., 2008.

INEGI, Comunicación social. Source: <http://www.inegi.org.mx/inegi/contenidos/espanol/prensa/ Boletines/Boletin/Comunicados/Especiales/2013/julio/comunica9.pdfs. Accesso: 14.02.2014.

KŁOSOWICZ, R., (ed.) Państwa dysfunkcyjne i ich destabilizujący wpływ na stosunki międzynarodowe, [Dysfunctional states and their destabilizing impact on international relations], Wydawnictwo UJ, Kraków, 2013.

MALENDOWSKI, W., MOJSIEWICZ, C., (eds.) Międzynatodowe stosunki polityczne, [International Political Relations], C., Atla 2, Wroclaw, 1998.

OJEDA GÓMEZ, M., Los Paises prioritarios para Mexico, in: Foro Internacional, v. 50, n. 1, Jan-Mar 2010. 
OXFORD POVERTY AND HUMAN DEVELOPMENT INITIATIVE, Multidimensional Poverty Index: 2011 Data. Source: <www.ophi.org.uk/policy/multidimensional-poverty-index/> Access: 09.08.2012.

PUBLIC PAPERS OF THE PRESIDENTS OF THE UNITED STATES, George W. Bush, Joint Statement by the United States of America and Mexico, March 14, 2007, Merida, Mexico, 2007, Book I, the U.S. Government Printing Office.

RAMÍREZ, S., Regionalism: the Pacific Alliance. Source: <http://www.americasquarterly.org/ content/regionalism-pacific-alliances. Access: 24.05.2014.

RIBANDO SEELKE, C., Supporting Criminal Justice System Reform in Mexico. The U.S. Role, Congressional Research Service, 2013. Source: <https://www.fas.org/sgp/crs/row/R43001. pdf>. Access: 12.02.2014.

RUíZ, J.L., Crea Centroamerica fuerzas contra los Zetas, El Universal, 28 de enero 2011.

RUÍZ PÉREZ, A., Los factores internos de la politica exterior mexicana: los sexenios de Carlos Salinas y Vicente Fox, in: Foro Internacional, v. 51, n. 2, Apr-Jul., 2011.

SECRETARÍA DE RELACIONES EXTERIORES, Programa Sectorial de Relaciones Exteriores 2013 - 2018, el 13 de Diciembre 2013. Source: <http://www.sre.gob.mx/images/ stories/marconormativodoc/dof131213-p.pdf>. Access: 26.05.2013.

SHIRK, D. A., Criminal Justice Reform in Mexico: An Overview, w: Mexican Law Review, v. 3, n. 2, 2010

SORIANO, J. P., Dilma y Mexico. Altibajos en una relación indispensable para America Latina, in: Revista CIDOB d'afers internacionals, n. 97-98, April 2012.

TRANSPARENCY INTERNATIONAL, Global Corruption Barometer 2013. Source: <http:// www.transparency.org/gcb2013/country/?country=mexico $>$. Access: 14.02.2014.

VILLANUEVA HALLAL, R., The Foreign Policy of Mexico, speech at the Institute of American Studies and Polish Diaspora, Jagiellonian University, Kraków, April 16 $6^{\text {th }}, 2014$.

VILLAREAL, M. A., Mexico's Free Trade Agreements, Congressional Research Service. Source: <https://www.fas.org/sgp/crs/row/R40784.pdf>. Access: 18.05.2014.

WORLD BANK. Source:<http://data.worldbank.org/indicator/>. Access: 24.05.2014.

Recebido: 29.04 .2015

Aceito: 01.08.2015 


\section{México: uma potência regional ou um Estado falido?}

\section{Resumo}

Há muitos anos que o México é considerado um dos países mais importantes na região da América Latina e Caribe. Essa opinião tem bons fundamentos. Território, localização geográfica, economia e impacto político são fatores fundamentais que predestinam esse país ao papel da potência regional. O processo de transição democrática que aconteceu no México nas últimas décadas assim como a cooperação com os Estados Unidos permitem o desempenho de um papel do líder regional.

Não obstante, México encontra também graves problemas que dificultam ao país o desempenho do papel de um verdadeiro líder. O mais importante é a questão do desenvolvimento do narco-business. Esse fenômeno leva não só a um aumento das atividades dos cartéis mas também causa uma erupção de narco-violência no México. Isso cria graves problemas para as autoridades mexicanas. O desenvolvimento do narco-business é por parte um resultado da fraqueza de certas instituições. Por exemplo: as forças policiais não reparam a ligação entre as suas atividades e o narcotráfico. Como efeito disso, o México não consegue garantir segurança aos seus cidadãos, que é uma das mais importantes funções de cada estado. Será que México consegue controlar o seu território? Certo é que definitivamente não tem monopólio do uso da violência. A grave corrupção permite aos diferentes atores não-estatais influenciar os processos decisórios. Todos esses problemas justificam a tese que em certas áreas o estado do México é disfuncional. Alguns analistas vão ainda mais longe, descrevendo o México como um estado falido.

O objetivo do artigo é analisar a posição presente do México na região da América Latina e Caribe. Será que os problemas contemporâneos são tão grandes que poderiam levar a uma queda do estado mexicano ou será que México tem o potencial para desempenhar o papel de líder e potência regional? O autor gostaria de investigar o impacto dos problemas internos atuais do México com relação à sua posição geopolítica.

Palauras-chave: México. Estado falido. Política exterior 